\title{
Assessment of Some Heavy Metals in Groundwater: Case Study Around an Archaeological Site, Abydos, Sohag, Egypt
}

\author{
Sherif Abu El-Magd ${ }^{1, *}$, Ahmed Abdel Moneim², Ahmed Sefelnasr ${ }^{3}$ \\ ${ }^{1}$ Geology Department, Faculty of Science, Suez University, Suez, Egypt \\ ${ }^{2}$ Geology Department, Faculty of Science, Sohag University, Sohag, Egypt \\ ${ }^{3}$ Geology Department, Faculty of Science, Assiut University, Assiut, Egypt
}

Email address:

sherif.abuelmagd@sci.suezuni.edu.eg (S. A. El-Magd)

${ }^{*}$ Corresponding author

To cite this article:

Sherif Abu El-Magd, Ahmed Abdel Moneim, Ahmed Sefelnasr. Assessment of Some Heavy Metals in Groundwater: Case Study Around an Archaeological Site, Abydos, Sohag, Egypt. Hydrology. Vol. 8, No. 3, 2020, pp. 34-40. doi: 10.11648/j.hyd.20200803.11

Received: July 2, 2020; Accepted: August 24, 2020; Published: September 3, 2020

\begin{abstract}
Water is extremely essentials for existence of the human life, livestock and plants. With grows of world population rapidly and increasing reclamation extension, their needs for water increased dramatically. However, the increase of water discharge and lack of the sewage treatment and system in the study area and adequate industrial disposal system increase the contamination. In the current study, analysis of heavy metals contamination has been studied around the Osireion Lake. The quality index of the collected groundwater samples indicated that the water is of poor to unsuitable water class for domestic use. Some heavy metals such, $\mathrm{B}-1, \mathrm{Al}+3, \mathrm{Fe}+3, \mathrm{Mn}+2, \mathrm{Ni}+2, \mathrm{Ba}+2, \mathrm{Cu}+2, \mathrm{~Pb}+2$, and $\mathrm{Sr}+2$ were measured in the in the present study to assess the risk factor. The heavy metals contamination has been reported as a potential risk in the groundwater in the study area. Iron and Manganese show some values higher than the maximum permissible of WHO. Iron might have resulted from the interaction of oxidized Fe minerals and organic matter. Strontium and Barium reveal higher values, therefore the higher concentrations of $\mathrm{Sr}^{+2}$ and $\mathrm{Ba}^{+2}$ indicating that the source could be a result of anthropogenic through fertilizer in agricultural activity causes an input of $\mathrm{Sr}^{+2}$ and $\mathrm{Ba}^{+2}$. It is believed that the mixing of groundwater with agricultural return flow and sewage waste, increase the concentration levels of pollutants.
\end{abstract}

Keywords: Quality Index, Heavy Metals, Osireion Lake, Abydos, Egypt

\section{Introduction}

Sohag Governorate located in the Upper Egypt at about 465 $\mathrm{km}$ distance south to Cairo, however, Sohag occupying about $125 \mathrm{~km}$ long from the Nile Valley the average width ranging from 16 to $20 \mathrm{~km}$. Abydos area located in El-Balyana city in the southwestern part of the Sohag Governorate, some of 70 kilometers from Sohag and about $13 \mathrm{Km}$. west of the Nile River, it is considered as one of the most important tourist sites in the county due to the importance of the presence of the temple of King Seti I and the Temple of Ramses II [1]. The area located between longitude $31^{\circ} 53^{\prime}$ and $31^{\circ} 57^{\prime} \mathrm{E}$ and latitude $26^{\circ} 10^{\prime}$ and $26^{\circ} 15^{\prime} \mathrm{N}$. Climatologically, Egypt belongs to arid belt; as a result of location Sohag to the south of Egypt, which characterized by hot summer, cold winter, and scarce rainfall with occasional storms. The recorded average value of precipitation was $2.25 \mathrm{~mm} / \mathrm{y}$ [2]. Several researchers have studied the chosen study area [3-6].

The aim of this study was to understand the source of some heavy metals around Osireion Lake. Heavy metals such as; $\mathrm{Fe}^{+3}, \mathrm{Mn}^{+2}, \mathrm{Cu}^{+2}, \mathrm{Zn}^{+2}, \mathrm{Co}^{+3}, \mathrm{Ni}^{+2}$ etc. are of importance for the functioning of the biological system and their deficiency or excess in the human system can lead number of disorders, other heavy metals such as $\mathrm{Pb}+2, \mathrm{As}+3, \mathrm{Hg}+2$ are not only biologically non-essential but even with low concentration levels could be toxic. Due to weathering, leaching and water interaction, soils normally have low background levels of heavy metals. In the area where the flooded irrigation has applied and industrial fertilizers have been used, the concentrations of specific heavy metals could 
be much higher. It's for sure that the higher concentration of heavy metals would be hazardous to human, animals, and plants. In this study, we shall report the heavy metals $\mathrm{B}^{-1}$, $\mathrm{Al}^{+3}, \mathrm{Fe}^{+3}, \mathrm{Mn}^{+2}, \mathrm{Ni}^{+2}, \mathrm{Ba}^{+2}, \mathrm{Cu}^{+2}, \mathrm{~Pb}^{+2}$, and $\mathrm{Sr}^{+2}$ concentration levels in groundwater around Osireion lake and the water of Osireion. Groundwater in the area west to this area normally used for land irrigation and to some extent for domestic use. Therefore, the groundwater within the Quaternary aquifer in the study area located under inhabitants, and reclaimed lands especially from the south of the Osireion Sacred Lake.

\section{Physiography of the Study Area}

\subsection{Geological Setting}

The area of study is a part of the Nile Valley that has been geologically investigated by many authors such as [7-10] The area of the Osireion is located $70 \mathrm{~km}$ south of Sohag on the west side of the Nile valley, at the border with Desert to the west. The plateau assumes an average elevation of $300 \mathrm{~m}$ above sea level, whereas the pediment surface has an average altitude of $100 \mathrm{~m}$ above sea level. The plateau runs in a very irregular course, including many promontories. The most conspicuous promontory is the one just $3 \mathrm{~km}$ due southwest (local west) of the Osireion. The exposed rock units in the study area are represented by Eocene shales and limestone and Quaternary sediments [7, 10]. The thick hard limestone section (Thebes Formation) forming the top of the scarp and plateau surface. The limestone has a residual thickness average +80 meters and constantly increases in thickness westward, (Figure 1) the Thebes belong to the Early Eocene. The pediment surface is covered by Quaternary sands and gravel getting to be muddy towards the East i.e., toward the cultivated part of the valley. The mud section $(+5 \mathrm{~m})$ overlooking the Osireion is known as the Dandara Formation, which represents the first Ethiopian sediment brought by the Nile from Ethiopia [10].

\subsection{Hydrological Setting}

Many authors such as [6, 12-14] have dealt with the hydrogeologic setting of the Sohag area. In the floodplain of the River Nile, the Quaternary aquifer system consists of fluvial sands with minor conglomerate and clay (Prenile, Qena Formation). It is capped with the Neonile silt and finegrained sands that constitutes the base of the cultivated lands. Along the eastern and western fringes, the Neonile silty layer is replaced by the recent sediments. Therefore, the aquifer system in the floodplain is under semi-confined condition (silty cap), but in the desert fringes it is under unconfined condition. The Qena sands are the main water bearing formation in the area and the formation thins out to the west abutting against the Paleocene to the Lower Eocene shales and limestones of the western Limestone Plateau. The groundwater level became higher than that of the Nile and consequently seepage from the aquifer to the Nile (return flow) created in the Nile Valley except in the upstream of barrages [14].

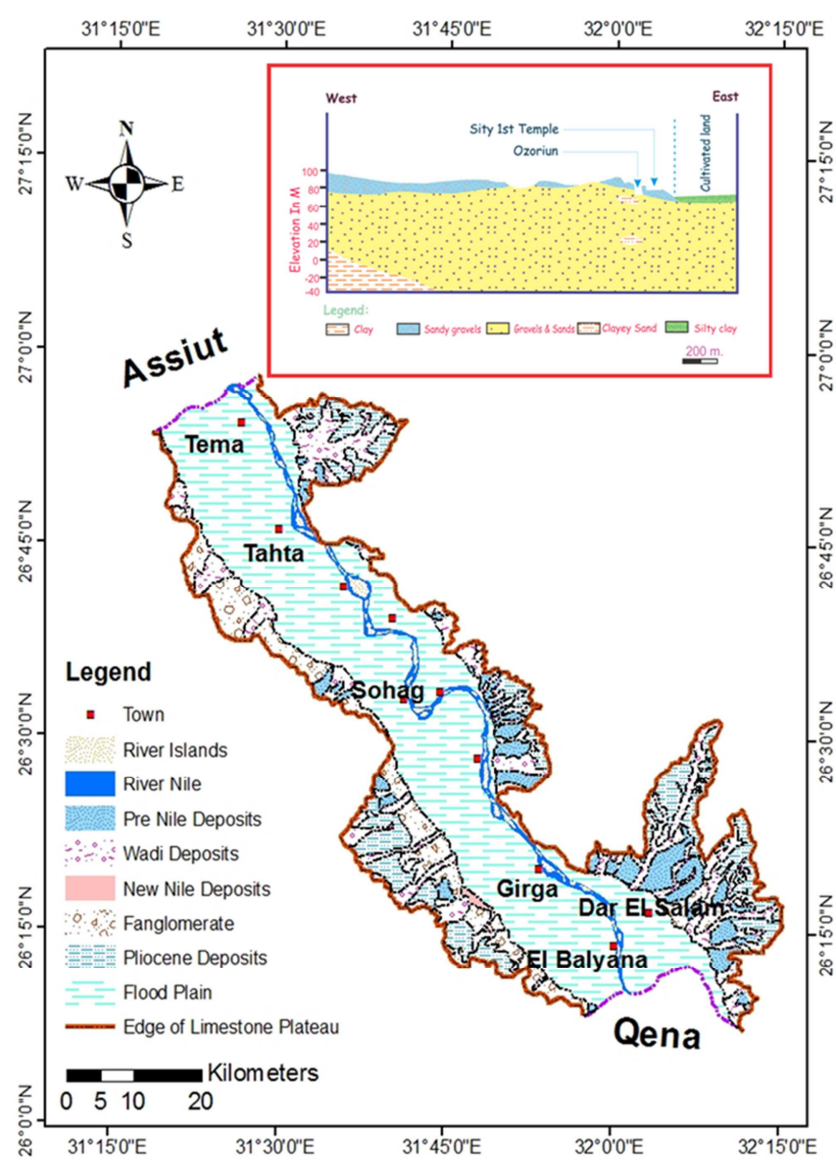

Figure 1. Geology of the study area (modified after, [11]).

The water level in the Osireion is about $13.30 \mathrm{~m}$ below around land surface, and the average water level in the Osireion is around $64 \mathrm{~m}$ amsl. Six drilled holes in year 2010 were submitted during this study around the Osireion in depth from $67 \mathrm{~m}$. to $104 \mathrm{~m}$ to investigate the water table. The water level in the drilled wells was recorded to be from $25 \mathrm{~m}$ to $29 \mathrm{~m}$ below the around ground surface. The aquifer thickness in the area of study ranging from 50 to $70 \mathrm{~m}$ with some clay intercalation [1]. Figure 1 show the geology of Sohag area and the cross section at Abydos site from westeast (Modified after, [6]).

\section{Materials and Methods}

Seven groundwater samples from the aquifer in and around the Osireion were collected in $1 \mathrm{~L}$ polyethylene bottles and acidified in the field by $\mathrm{HNO}_{3}$. Wells were pumping before collecting water, to remove stagnant water if found from the well pipe. Osireion water samples collected from the Osireion Lake, which is currently open as water accumulation. The $\mathrm{pH}$ meter kit was used to measure the $\mathrm{pH}$ values of collected water in the field. Portable kit with electrodes were used to get the values of electrical conductivity (EC) in the site. The heavy metals such as; $\mathrm{B}^{-1}$, $\mathrm{Al}^{+3}, \mathrm{Ba}^{+2}, \mathrm{Cu}^{+2}, \mathrm{Fe}^{+3}, \mathrm{Mn}^{+2}, \mathrm{Ni}^{+2}, \mathrm{~Pb}^{+2}$, and $\mathrm{Sr}^{+2}$, were carried out in Geochemistry Laboratory, Sohag Univ., Sohag, 
Egypt, summary of statistics are shown (Table 1).
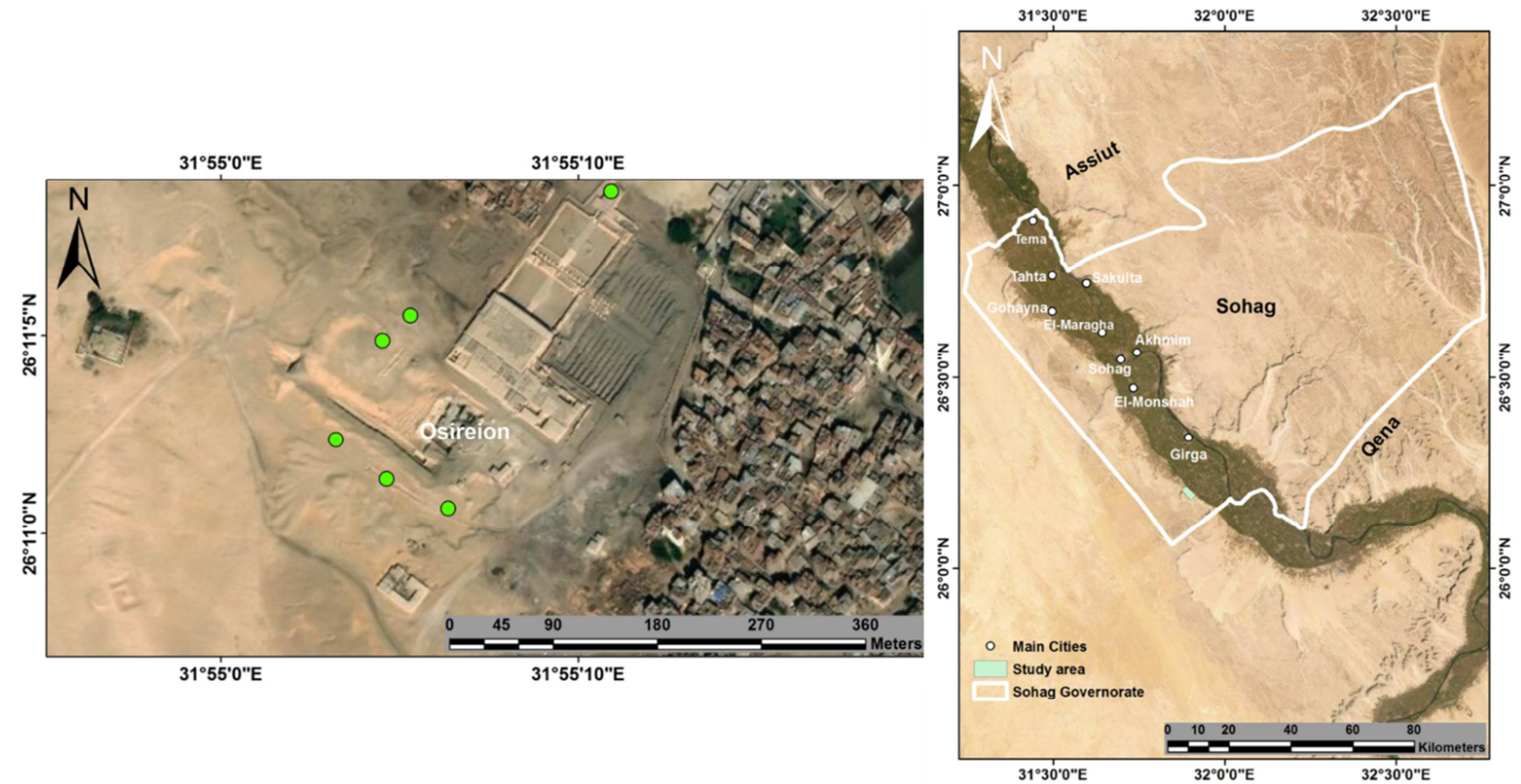

Figure 2. Location map of the study area.

Table 1. Physio-Chemical results of groundwater samples.

\begin{tabular}{|c|c|c|c|c|c|c|c|}
\hline & Range & Minimum & Maximum & Mean & Std. Deviation & Skewness & Kurtosis \\
\hline $\mathrm{pH}$ & 1.06 & 7.48 & 8.54 & 7.76 & 0.35 & 2.29 & 5.68 \\
\hline Ec & 3992.00 & 1438.00 & 5430.00 & 2958.00 & 1736.59 & 0.97 & -1.04 \\
\hline TDS & 2542.00 & 920.00 & 3462.00 & 1619.86 & 865.45 & 1.99 & 4.58 \\
\hline $\mathrm{Ca}^{+2}$ & 134.60 & 74.90 & 209.50 & 134.71 & 51.12 & 0.57 & -1.11 \\
\hline $\mathrm{K}^{+1}$ & 74.70 & 26.30 & 101.00 & 52.13 & 25.41 & 1.29 & 1.73 \\
\hline $\mathrm{Mg}^{+2}$ & 28.40 & 29.80 & 58.20 & 39.11 & 12.68 & 1.16 & -0.87 \\
\hline $\mathrm{Na}^{+1}$ & 348.00 & 150.00 & 498.00 & 321.86 & 134.20 & 0.41 & -1.18 \\
\hline $\mathrm{HCO}_{3}^{-1}$ & 289.16 & 219.60 & 508.76 & 404.89 & 100.23 & -1.09 & 1.02 \\
\hline $\mathrm{Cl}^{-1}$ & 380.00 & 160.00 & 540.00 & 388.57 & 134.96 & -0.57 & -0.13 \\
\hline $\mathrm{NO}_{3}^{-1}$ & 10.62 & 0.18 & 10.80 & 4.51 & 4.26 & 0.43 & -1.67 \\
\hline $\mathrm{SO}_{4}^{-2}$ & 500.00 & 160.00 & 660.00 & 330.00 & 218.25 & 1.02 & -0.99 \\
\hline $\mathrm{Al}^{+3}$ & 13.41 & 0.99 & 14.40 & 3.36 & 4.89 & 2.60 & 6.81 \\
\hline $\mathrm{Fe}^{+3}$ & 8.76 & 0.05 & 8.81 & 1.66 & 3.18 & 2.56 & 6.64 \\
\hline $\mathrm{Mn}^{+2}$ & 4.14 & 0.22 & 4.36 & 1.23 & 1.43 & 2.27 & 5.50 \\
\hline $\mathrm{Cu}^{+2}$ & 0.09 & 0.00 & 0.09 & 0.03 & 0.03 & 0.83 & -0.05 \\
\hline $\mathrm{Ni}^{+2}$ & 0.04 & 0.01 & 0.04 & 0.02 & 0.01 & 1.61 & 2.23 \\
\hline $\mathrm{Pb}^{+2}$ & 0.04 & 0.01 & 0.05 & 0.02 & 0.02 & 0.92 & -1.26 \\
\hline $\mathrm{Sr}^{+2}$ & 1.17 & 0.13 & 1.30 & 0.66 & 0.46 & 0.38 & -1.99 \\
\hline
\end{tabular}

* All concentrations mentioned above are given in (mg/l).

\section{Results and Discussion}

The $\mathrm{pH}$ was measured at the sample collection site using kid tools of electrodes, to avoid $\mathrm{pH}$ changes caused by escape of $\mathrm{CO}_{2}^{-2}$ and it ranges between 7.48 and 8.54. Electrical Conductivity values ranged between 1.45 to 5.43 mmhos in the study area. The results of ${ }^{n}$ chemical analysis of groundwater samples show that the concentrations of major anions $\mathrm{SO}_{4}^{-2}, \mathrm{HCO}_{3}{ }^{-1}, \mathrm{Cl}^{-1}$, and $\mathrm{NO}_{3}{ }^{-1}$ were in the ranges of 160 to $660,219.60$ to $508.76,160$ to 540 and less than 0.2 to $10.80 \mathrm{mg} / \mathrm{l}$, respectively. Where phosphate it was reported as less than $0.2 \mathrm{mg} / 1$. Major cations, $\mathrm{Na}^{+1}, \mathrm{~K}^{+1}, \mathrm{Ca}^{+2}$ and
$\mathrm{Mg}^{+2}$ had concentration levels in the range of 150 to 498 , 26.30 to $101,74.9$ to 196 and 29.80 to $58 \mathrm{mg} / 1$, respectively. Two major groups of groundwater, characterized by distinct chemical compositions, had been identified, which were, Na$\mathrm{HCO}_{3}$ type and $\mathrm{Na}-\mathrm{Cl}$ type. The hydrochemical results displays some of heavy metals are above the permissible limits, the results are presented in the (Table 1).

\subsection{Spatial Distribution of Data}

In 2014 Abdalla, et al. [15] study the heavy metals in Nag Hammadi area, located to the south of our present study. He concluded that the detection levels of heavy metals in Nag 
Hammadi of $\mathrm{Zn}^{+2}, \mathrm{Cu}^{+2}$ and $\mathrm{Pb}^{+2}$ in sediment and surface water samples were of high concentration than those of groundwater samples of the study area. Moreover, comparing of the concentration levels of some heavy metals in the study area with those of groundwater at Nag Hammadi, indicating the concentration levels in the study area were higher than those of Nag Hammadi for $\mathrm{Fe}^{+3}, \mathrm{Mn}^{+2}, \mathrm{Cu}^{+2}$, and $\mathrm{Pb}^{+2}$ (Table 2). The correlation matrix of chemical data Osireion and around groundwater samples are represented in (Table 3).
High correlation $(>0.75)$ which observed between $\mathrm{Fe}^{+3}$ and $\mathrm{Pb}^{+2}, \mathrm{Ba}^{+2}$ and $\mathrm{Pb}^{+2}, \mathrm{Ba}^{+2}$ and $\mathrm{Pb}^{+2}$ as well as $\mathrm{Al}^{+3}$ and $\mathrm{Ba}^{+2}$, $\mathrm{Al}^{+3}$ and $\mathrm{Fe}^{+3}$, and $\mathrm{Ba}^{+2}$ with $\mathrm{Pb}^{+2}$. High correlation values are observed between $\mathrm{Cl}^{-1}$ and $\mathrm{NO}_{3}{ }^{-1}, \mathrm{Na}^{+1}$ with $\mathrm{Cl}^{-1}, \mathrm{NO}_{3}{ }^{-1}$, and $\mathrm{SO}_{4}^{-2}$, which above $0.75 . \mathrm{Mg}^{+2}$ shows high correlation values with $\mathrm{Na}^{+1}, \mathrm{Cl}^{-1}$, and $\mathrm{SO}_{4}^{-2}$ as well as $\mathrm{Ca}^{+2}$ shows the high correlation values with $\mathrm{Mg}^{+2}$ and $\mathrm{Na}^{+1}$. The high correlation values in the study area may be contributed to the uses of pesticides as well as the fertilizers.

Table 2. Concentration levels of the study area and the Nag Hammadi area.

\begin{tabular}{|c|c|c|c|c|c|c|}
\hline$\mu \mathrm{g} / \mathrm{l}$ & & $\mathrm{Fe}^{+3}$ & $\mathrm{Mn}^{+2}$ & $\mathrm{Zn}^{+2}$ & $\mathrm{Cu}^{+2}$ & $\mathbf{P b}^{+2}$ \\
\hline \multirow{2}{*}{ Study Area } & Mini. & 0.050 & 0.220 & -- & 0.000 & 0.005 \\
\hline & Max. & 8.810 & 4.360 & -- & 0.090 & 0.050 \\
\hline Nag Hamaadi & Mini. & 0.041 & 0.003 & 0.004 & 0.002 & 0.004 \\
\hline
\end{tabular}

Table 3. Correlation matrix of the chemical data of the study area.

\begin{tabular}{|c|c|c|c|c|c|c|c|c|}
\hline Element & $\mathrm{B}^{-1}$ & $\mathrm{Ca}^{+2}$ & $\mathbf{K}^{+1}$ & $\mathrm{Mg}^{+2}$ & $\mathrm{Na}^{+1}$ & $\mathrm{Cl}^{-1}$ & $\mathrm{NO}_{3}{ }^{-1}$ & $\mathrm{SO}_{4}{ }^{-2}$ \\
\hline $\mathrm{B}^{-1}$ & 1 & & & & & & & \\
\hline $\mathrm{Ca}^{+2}$ & 0.39 & 1 & & & & & & \\
\hline $\mathrm{K}^{+1}$ & 0.91 & 0.46 & 1 & & & & & \\
\hline $\mathrm{Mg}^{+2}$ & 0.39 & 0.98 & 0.53 & 1 & & & & \\
\hline $\mathrm{Na}^{+1}$ & 0.21 & 0.79 & 0.49 & 0.87 & 1 & & & \\
\hline $\mathrm{Cl}^{-1}$ & 0.18 & 0.60 & 0.49 & 0.70 & 0.96 & 1 & & \\
\hline $\mathrm{NO}_{3}{ }^{-1}$ & 0.22 & -0.41 & -0.17 & -0.56 & -0.80 & -0.80 & 1 & \\
\hline $\mathrm{Al}^{+3}$ & -0.31 & 0.63 & -0.24 & 0.56 & 0.55 & 0.45 & -0.35 & 0.53 \\
\hline $\mathrm{Ba}^{+2}$ & -0.72 & 0.29 & -0.54 & 0.30 & 0.47 & 0.43 & -0.60 & 0.32 \\
\hline $\mathrm{Cu}^{+2}$ & -0.59 & -0.44 & -0.34 & -0.37 & -0.04 & 0.12 & -0.34 & -0.35 \\
\hline $\mathrm{Fe}^{+3}$ & -0.29 & 0.67 & -0.21 & 0.60 & 0.56 & 0.45 & -0.37 & 0.57 \\
\hline $\mathrm{Mn}^{+2}$ & 0.69 & 0.41 & 0.83 & 0.53 & 0.50 & 0.46 & -0.40 & 0.54 \\
\hline $\mathrm{Ni}^{+2}$ & -0.19 & -0.26 & 0.10 & -0.08 & 0.31 & 0.46 & -0.62 & -0.07 \\
\hline $\mathrm{Pb}^{+2}$ & -0.57 & 0.42 & -0.38 & 0.42 & 0.56 & 0.53 & -0.57 & 0.40 \\
\hline $\mathrm{Sr}^{+2}$ & 0.26 & -0.16 & 0.40 & -0.03 & 0.26 & 0.41 & -0.30 & -0.07 \\
\hline
\end{tabular}

Table 3. Continued.

\begin{tabular}{|c|c|c|c|c|c|c|c|c|}
\hline Element & $\mathbf{A l}^{+3}$ & $\mathrm{Ba}^{+2}$ & $\mathrm{Cu}^{+2}$ & $\mathrm{Fe}^{+3}$ & $\mathrm{Mn}^{+2}$ & $\mathrm{Ni}^{+2}$ & $\mathbf{P b}^{+2}$ & $\mathrm{Sr}^{+2}$ \\
\hline \multicolumn{9}{|l|}{$\mathrm{B}^{-1}$} \\
\hline \multicolumn{9}{|l|}{$\mathrm{Ca}^{+2}$} \\
\hline \multicolumn{9}{|l|}{$\mathrm{K}^{+1}$} \\
\hline \multicolumn{9}{|l|}{$\mathrm{Mg}^{+2}$} \\
\hline \multicolumn{9}{|l|}{$\mathrm{Na}^{+1}$} \\
\hline \multicolumn{9}{|l|}{$\mathrm{Cl}^{-1}$} \\
\hline \multicolumn{9}{|l|}{$\mathrm{NO}_{3}{ }^{-1}$} \\
\hline $\mathrm{Al}^{+3}$ & 1 & & & & & & & \\
\hline $\mathrm{Ba}^{+2}$ & 0.78 & 1 & & & & & & \\
\hline $\mathrm{Cu}^{+2}$ & 0.16 & 0.33 & 1 & & & & & \\
\hline $\mathrm{Fe}^{+3}$ & 1.00 & 0.77 & 0.13 & 1 & & & & \\
\hline $\mathrm{Mn}^{+2}$ & -0.38 & -0.37 & -0.46 & -0.35 & 1 & & & \\
\hline $\mathrm{Ni}^{+2}$ & -0.34 & 0.19 & 0.25 & -0.35 & 0.43 & 1 & & \\
\hline $\mathrm{Pb}^{+2}$ & 0.92 & 0.94 & 0.41 & 0.91 & -0.40 & 0.00 & 1 & \\
\hline
\end{tabular}

\subsection{Water Quality Index}

To evaluate the water quality in the present study, water quality index has been used. The water quality index has been introduced [16] and five water quality classes have been identified. The water quality index can be calculated as the following Equation (4).

$$
q_{n}=100 \frac{V_{n}-V_{i}}{s_{n}-V_{i}}
$$

Where $q_{n}$ is water quality rating for the $n$th parameter, $V_{n}$ is measured value of the $n$th parameter, and $S_{n}$ is the standard permissible value of nth parameter. To calculate the water quality index, weighted units $\left(\mathrm{W}_{\mathrm{n}}\right)$ and the constant for proportionality $(\mathrm{K})$ has to be calculated as follows, Equations 
(2 and 3$)$.

$$
\begin{gathered}
W_{n}=\frac{K}{s_{n}} \\
K=\frac{1}{\sum^{1} / s_{n}} \\
W Q I=\sum q_{n} W_{n} / \sum W_{n}
\end{gathered}
$$

Using the above mention Equations (1 to 4) to calculate the water quality index for the study area. Table 4 shows the calculated results of water quality rating, weighted unit, constant for probability, and water quality index; the above Equations. The analyzed data in the present study were compared to WHO guidelines [17-21]. The index of water quality results shows that all the samples were above 100 except W2, which was 70, indicating poor to unsuitable

\begin{tabular}{|c|c|c|c|c|c|c|c|c|}
\hline Element & Standard Value & Measured Value & 1/Sn & $\mathbf{K}$ & Wn & qn & $\mathbf{W n} * \mathbf{Q n}$ & WQI \\
\hline $\mathrm{pH}$ & 8.50 & 7.69 & 0.118 & \multirow{14}{*}{0.016} & 0.002 & 59.5 & 0.11 & \multirow{15}{*}{70.42} \\
\hline $\mathrm{EC}$ & 1500.00 & 1964.00 & 0.001 & & 0.000 & 130.9 & 0.00 & \\
\hline TDS & 1500.00 & 1257.00 & 0.001 & & 0.000 & 83.8 & 0.00 & \\
\hline $\mathrm{Ca}^{+2}$ & 200.00 & 114.10 & 0.005 & & 0.000 & 57.1 & 0.00 & \\
\hline $\mathrm{K}^{+1}$ & 12.00 & 32.00 & 0.083 & & 0.001 & 266.7 & 0.36 & \\
\hline $\mathrm{Mg}^{+2}$ & 125.00 & 33.60 & 0.008 & & 0.000 & 26.9 & 0.00 & \\
\hline $\mathrm{Na}^{+1}$ & 200.00 & 150.00 & 0.005 & & 0.000 & 75.0 & 0.01 & \\
\hline $\mathrm{Cl}^{-1}$ & 250.00 & 160.00 & 0.004 & & 0.000 & 64.0 & 0.00 & \\
\hline $\mathrm{NO}_{3}{ }^{-1}$ & 50.00 & 8.65 & 0.020 & & 0.000 & 17.3 & 0.01 & \\
\hline $\mathrm{SO}_{4}^{-2}$ & 250.00 & 270.00 & 0.004 & & 0.000 & 108.0 & 0.01 & \\
\hline $\mathrm{Al}^{+3}$ & 0.20 & 0.99 & 5.000 & & 0.082 & 495.5 & 40.56 & \\
\hline $\mathrm{Fe}^{+3}$ & 0.30 & 0.17 & 3.333 & & 0.055 & 55.0 & 3.00 & \\
\hline $\mathrm{Mn}^{+2}$ & 0.50 & 0.90 & 2.000 & & 0.033 & 179.4 & 5.87 & \\
\hline $\mathrm{Cu}^{+2}$ & 2.00 & 0.00 & 0.500 & & 0.008 & 0.1 & 0.00 & \\
\hline Sum & & & 61.085 & 0.016 & 1.000 & & 70.42 & \\
\hline
\end{tabular}
water for domestic use classes (Table 5).

Table 4. Water quality index (WQI) for individual element (units in $\mathrm{mg} / \mathrm{l}$ ).

Table 5. Water quality index classes of the study area.

\begin{tabular}{lll}
\hline Class & WQI & Study area \\
\hline Excellent & $<50$ & \\
Good & $51-100$ & W2 \\
Poor & $101-200$ & W1, W3, W6, W7 \\
Very Poor & $201-300$ & W4 \\
Un Suitable & $>300$ & W5 \\
\hline
\end{tabular}

\subsection{Heavy Metals}

The detected levels of heavy metals in the study area such as; $\mathrm{Pb}^{+2}, \mathrm{Sr}^{+2}, \mathrm{Cu}^{+2}, \mathrm{Fe}^{+3}, \mathrm{~B}^{-1}, \mathrm{Mn}^{+2}$, and $\mathrm{Al}^{+3}$ was compared with those values reported by WHO. The sources of lead in groundwater would come where diesel fuel consumed on farms, discarded batteries, paint and leaded gasoline. WHO, reported that the consumption in higher quantity of $\mathrm{Pb}^{+2}$, might cause hearing loss, blood disorders, hypertension and eventually, it may prove to be fatal [17]. Concentration of $\mathrm{Pb}^{+2}$ found in the study area ranged between less than 0.005 and $0.05 \mathrm{mg} / \mathrm{l}$. All the collected samples analyzed, have concentration levels less than the maximum permissible limit of $0.10 \mathrm{mg} / \mathrm{l}$. Concentration of $\mathrm{As}^{+3}$ in the study area found less than $0.01 \mathrm{mg} / \mathrm{l}$ in all the collected samples and it is observed that the concentration of As under the limit of the maximum permissible level of [17]. $\mathrm{Sr}^{+2}$ minerals can be released to the groundwater from the weathering of rocks and soils. In the study area concentration of $\mathrm{Sr}^{+2}$ was reported more than the permissible limit of $0.07 \mathrm{mg} / 1$ [18], and it was observed in the range of 0.13 to $1.30 \mathrm{mg} / \mathrm{l}$. The higher concentrations, indicating that the source could be anthropogenic through agricultural activity causes an input of $\mathrm{Sr}^{+2}$, to some extent it depends on the content of fertilizers and carbonate additives and manure likes cattle, poultry [22].

Table 6. Struntium classes in the study area.

\begin{tabular}{llll}
\hline Category & Limits & Study area & Remarks \\
\hline Fresh Water & $<1.6$ & $0.13-1.3$ & Study area fall within fresh water \\
Brackish Water & $1.6-5.0$ & - & - \\
Saline Water & $>5.0$ & - & \\
\hline
\end{tabular}

Saxena et al. [23] have established that $\mathrm{Sr}^{+2}$ content could be linked to various water types [23]. They suggested $\mathrm{Sr}^{+2}$ values of $<1.6 \mathrm{mg} / \mathrm{l}$ for fresh groundwater, $1.6-5.0 \mathrm{mg} / \mathrm{l}$ for brackish water, and $>5.0 \mathrm{mg} / \mathrm{l}$ for saline groundwater in the coastal aquifers (Table 6). The $\mathrm{Sr}^{+2}$ values obtained indicated that the all groundwater samples fall within the freshwater 
category according to the above classification.

It is known that the copper found in plants, animal and human bodies, with very small amounts. The copper comes normally into life bodies through water, soil or industrials actives. The high concentration of $\mathrm{Cu}^{+2}$ would be of dangerous or toxic for life. However, the WHO reported the toxic limit of $\mathrm{Cu}^{+2}$ and mentioned that the $\mathrm{Cu}^{+2}$ was an essential in metabolism of human bodies and up to $0.05 \mathrm{mg} / \mathrm{l}$ was considered to be non-toxic [21]. Meanwhile, all the samples in the study area, reveals that they were within the maximum permissible limit of $1.5 \mathrm{mg} / \mathrm{l}$ and $\mathrm{Cu}^{+2}$ concentration levels ranged from 0.004 to $0.091 \mathrm{mg} / \mathrm{l}$. The higher concentrations of iron may cause toxic effect on human health. The $\mathrm{Fe}^{+3}$ concentration was recorded in the study area between 0.05 and $8.81 \mathrm{mg} / \mathrm{l}$. High level of $\mathrm{Fe}^{+3}$ concentrations was reported in all samples in the study area than the concentration level reported in [20]. Higher $\mathrm{Fe}^{+3}$ concentrations in the aquifers might have resulted from the interaction of oxidized $\mathrm{Fe}^{+3}$ minerals and organic matter and subsequent. Boron $\left(\mathrm{B}^{-1}\right)$ in groundwater may have several possible human affected sources, including wastewater effluent, and laundry detergent; possible natural sources include leaching of geologic materials and mixing of groundwater, [24]. Boron usually occurs as a non-ionized form as $\mathrm{H}_{3} \mathrm{BO}_{3}$ in soils at $\mathrm{pH}<8.5$, but above this $\mathrm{pH}$, it exists as an anion, $\mathrm{B}(\mathrm{OH})_{4},[25]$. In the present study, Boron concentration ranged from 0.152 to $0.406 \mathrm{mg} / \mathrm{l}$, where the maximum permissible limit of $\mathrm{B}^{-1}$ was $0.3 \mathrm{mg} / 1$ [18]. Samples record the concentration of Boron more than the permissible limit of [18] except W1 and W4 which are less than those reported by WHO. WHO reported that there is little indication that aluminum is acutely toxic by oral exposure despite its widespread occurrence in foods, drinking water, and many antacid preparations [19]. In the study area $\mathrm{Al}^{+3}$ was reported to be between 0.991 to $14.4 \mathrm{mg} / \mathrm{l}$, it is observed that all the collected samples are above the maximum permissible level [21]. In general, in term of aluminum concentration in the study area were contributed to high risks. The weathering of manganese bearing rock and menials is mostly responsible for releasing manganese; accordingly, it will be a common source of manganese in water. Local groundwater could receive the manganese from leaching of manganese from municipal and industrials activates. $\mathrm{Mn}^{+2}$ concentration was reported in the samples in the range of 0.22 to $4.36 \mathrm{mg} / \mathrm{l}$. it is obvious that all the samples in the area of study, are of concentration level higher than the maximum permissible limits $0.1 \mathrm{mg} / 1$ reported by [18]. Concentration of Nickel $\left(\mathrm{Ni}^{+2}\right)$ reported to be less than the concentration levels of [21] in the present study, having $\mathrm{Ni}$ levels ranges from less than 0.005 to $0.04 \mathrm{mg} / \mathrm{l}$.

\section{Pollution Index}

Pollution index (Pi) is defined as the ratios of the concentration of individual parameter against the baseline standard (Table 7). It provides information on the relative pollution contributed by individual samples. The critical value is 1.0 , values greater than 1.0 indicates a significant degree of pollution while values less than 1.0 shows no pollution [26]. Pollution Index (Pi) is computed as:

$$
\text { Pollution Index }(\mathrm{Pi})=(\text { Concentration/Standard })
$$

Table 7. Pollution Index for heavy elements in the study area

\begin{tabular}{|c|c|c|c|c|c|c|c|}
\hline Element & W1 & W2 & W3 & W4 & W5 & W6 & Osireion \\
\hline Boron & 0.51 & 1.02 & 1.25 & 0.90 & 0.99 & 1.35 & 1.10 \\
\hline Aluminum & 8.90 & 4.96 & 10.90 & 6.50 & 72.00 & 5.05 & 9.40 \\
\hline Barium & 0.03 & 0.09 & 0.06 & 0.14 & 0.18 & 0.06 & 0.06 \\
\hline Copper & 0.06 & - & 0.00 & 0.03 & 0.02 & - & 0.04 \\
\hline Iron & 1.27 & 0.17 & 0.58 & 0.05 & 8.81 & 0.29 & 0.49 \\
\hline Manganese & 0.44 & 1.79 & 1.98 & 2.58 & 0.74 & 8.72 & 0.99 \\
\hline Lead & 0.48 & - & - & 0.21 & 0.46 & - & 0.10 \\
\hline
\end{tabular}

The pollution Index value is presented in (Table 7), which calculated using Equation (5). The values obtained of pollution index for B, in $\mathrm{W} 2, \mathrm{~W} 3, \mathrm{~W} 6$ and Osireion are of significant degrees of pollution. Values for $\mathrm{Al}^{+3}$ as well as $\mathrm{Sr}^{+2}$ in all collected samples shows a high degree of pollution. It is observed that the Pi values for iron reported as greater than the 1 in well ( 1 and 5) which a significant degree of pollution. The values obtained for $\mathrm{Mn}^{+2}$, in $\mathrm{W} 2, \mathrm{~W} 3, \mathrm{~W} 4$ and W6 are of significant degrees of pollution.

\section{Conclusion}

Water quality index in the area reveals the most of the collected groundwater samples were located in poor to unsuitable water for municipal use. The hydrochemical analysis of collected samples in the present study reveals that the groundwater is contaminated with some metals, such as $\mathrm{Fe}^{+3}, \mathrm{Mn}^{+2}, \mathrm{Al}^{+3}, \mathrm{~B}^{-1}$, and $\mathrm{Sr}^{+2}$. This contamination has been caused by, municipal waste disposal sites and agriculture fertilization. Moreover, high levels of $\mathrm{Ba}^{+2}$ in some samples are suspected to originate from fertilizers and pesticide from return flow of agricultural activities. The concentrations of some heavy metals have already exceeded the maximum limit WHO standards. Despite of municipal activity is located few meters above the layer of the aquifer; using hand-dug well for their waste disposal. The correlation relation displays that the heavy metals concentrations is not completely associated with the aquifer rock unit's interaction indicating an additional anthropogenic source. The anthropogenic contribution is sufficiently high in the effect on increasing the contamination levels; which were quite related to municipal disposal, fertilization and industrial discharges. 


\section{Acknowledgements}

The authors are thankful to an anonymous reviewer for their valuable suggestions to improve the manuscript in the present form.

\section{References}

[1] Sefelnasr A., Abdel Moneim A., Abu El-Magd Sh. (2015): Groundwater level-rise monitoring and recharge determination at an old archeological site: Abydos, Sohag, Egypt. Eighth Int. Conf. on Geology of Africa, P-P IV- 69-IV 83. Assiut-Egypt.

[2] Meteorological Authority of Egypt (MAE), (2000): Meteorological database, Cairo, Egypt.

[3] Abdel Hafez, T. M. (2004): Geophysical and Geotechnical studies in Pharaonic and Urban Egypt, Inaugural Dissertation Universitat Bern.

[4] Abdel Kareem, H. H. (1972): Geology of the area east of the Nile Valley between Sohag and Girga. M. Sc. thesis, Geol. Dept. Fac. Sci., Assiut University, Egypt. 250 p.

[5] Abdel Moneim, A. A. (1988): Hydrogeology of the Nile Valley at Sohag province. M. Sc. thesis, Geology Dept. Faculty of Science, Sohag, Assiut University, $150 \mathrm{p}$.

[6] Abdel Moneim, A. A. (1992): Numerical simulation and ground water management of the Sohag aquifer, the Nile Valley, Egypt. Ph. D. Thesis civil Eng. Dept. Strathclyde Univ., Glasgow, Scotland, Great Britain.

[7] Said, R. (1981): The geological evaluation of the River Nile. Springer Verlag, New York 151p.

[8] Said, R. (1983): Proposed classification of the Quaternary of Egypt. Jour. of African Earth Sciences. V. 1, p. 41-45.

[9] Brooks, J. and Issawi B. (1992): Groundwater in the Abydos Areas, Egypt; The flooding of the Osireion, Water paper 5; 1992.

[10] Omer, A. A. (1996): Geological, mineralogical and geochemical studies on the Neogene and Quaternary Nile basin deposits, Qena-Assiut stretch, Egypt. Ph. D. thesis, Geology Dept. Faculty of Science, Sohag, South Valley University, $320 \mathrm{p}$.

[11] CONOCO, (1987): Geologic Map of Egypt. Egyptian General Authority for Petroleum (UNESCO Joint Map Project), 20 Sheets, Scale 1: 500 000. Cairo.

[12] Attia, F. A., (1974): Parameter and characteristics of the groundwater reservoir in Upper Egypt. MSc Thesis, Fac. Eng. Cairo Univ., Egypt.
[13] Attia, F. A. (1985): Management of water systems in Upper Egypt. Ph. D. Thesis, Fac Eng, Cairo Univ., Egypt.

[14] Farrag, A. A., (2005): The hydraulic and hydrochemical impacts of the Nile system on the groundwater in Upper Egypt. Ass. Univ. Bull. Environ. Res. Vol. 8 No. 1, March 2005.

[15] Abdalla, F., Madkour, H., Mohamed, A., Ahmed, A., and Obirikorang, K. (2014): Heavy metal distributions in the Quaternary aquifer as influenced by polluted agricultural drain, Nag-Hammadi area, Qena, Egypt. The 7th Int. Conf. for Develop. and the Env. in the Arab world, March, 23-25.

[16] Brown, R. M., Mc Clelland, N. I., Deininger, R. A., and Tozer, R. G. (1970): A water quality index: do we dare? Water and sewage work 117 (1970) 339e343.

[17] World Health Organization (WHO), (1993): Guidelines for drinking water quality, Vol. 1. WHO, Geneva.

[18] World Health Organization (WHO), (1994): Fluoride and oral health, World Health Organization Tech. Rep. Sec., 846, Geneva.

[19] World Health Organization (WHO), (1996): Guidelines for drinking water quality, (2nd edition). World Health Organization, Geneva. Vol. 2. Health criteria and other supporting information: 940-949.

[20] World Health Organization (WHO), (2008): Guidelines for drinking-water quality [electronic resource]: incorporating $1 \mathrm{st}$ and 2nd addenda, vol. 1, Recommendations, third ed. World Health Organization, Geneva.

[21] World Health Organization (WHO), (2011): Guidelines for drinking-water quality, fourth ed. World Health Organization, Geneva.

[22] Négrel, Ph., Petelet-Giraud, E., and Widory, D. (2004): Strontium isotope geochemistry of alluvial groundwater: a tracer for groundwater resources characterisation. Hydrology and Earth System Sciences Discussions, European Geosciences Union, 2004, 8 (5), pp. 959-972.

[23] Saxena, V., Mondal N., and Singh V. (2004): Identification of seawater ingress using Strontium and Boron in Krishna delta, India. Curr. Sci., 86 (4): 586-590.

[24] Davidson, G. and Bassett, R. (1993): Application of boron isotopes for identifying contaminants such as fly ash leachate in groundwater. Environ. Sci. Technol. 27 (1), 172-176.

[25] Miller, R. and Donahue R. (1995): Soils in our environment, 7th ed. Englewood Cliffs, NJ: Prentice Hall.

[26] Akpoveta, O. V., Okoh B. E. and Osakwe, S. A. (2011): Quality assessment of borehole water used in the vicinities of Benin, Edo State and Agbor, Delta State of Nigeria. Current Research in Chemistry, 3: 62-69. 